\title{
PREVALENCE OF URINARY TRACT INFECTION IN PREGNANT WOMEN
}

Dr. Nawaz Umar, Dr. Siddesh Basavaraj. Sirwar

1. Assistant Professor, Department of Microbiology, Khaja Banda Nawaz Institute of Medical Sciences, Gulbarga Karnataka.

2. Professor, Department of Microbiology, Khaja Banda Nawaz Institute of Medical Sciences, Gulbarga Karnataka.

\section{CORRESPONDING AUTHOR}

Dr. Nawaz Umar,

C/O Mohd Umar "Ayesha Mansion",

Near Baogi Hospital, Aiwan Shahi colony,

Gulbarga, Karnataka 585102,

E-mail: drnawazumar@gmail.com,

Ph: 00919945270149.

ABSTRACT: Urinary tract infection is one of the most frequently seen medical complications in pregnancy. UTI in pregnancy is an important concern, as it possesses risk of complications such as acute and chronic pyelonephritis, toxaemia, anaemia, hypertension, intrauterine growth retardation and increased perinatal mortality. The detection of bacteriuria allows an approach to be made for the prevention of chronic urinary disease in the community and to avoid complications in pregnancy at an early stage. OBJECTIVES: (1) To study the prevalence of bacterial pathogens causing urinary tract infection among pregnant women; (2) To evaluate the sensitivity of the screening test with culture. MATERIALS AND METHODS: A total of 500 samples were investigated from pregnant women aged between 18 to 35 years, with varying gravida and from all three trimesters were included in a period of one year i.e., from January to December 2011. The samples were collected aseptically from women attending the antenatal clinic at the Khaja Banda Nawaz Hospital, Gulbarga. Urine was collected in the sterile urine container. Both macroscopic and microscopic examination was done. Screening tests like Griess Nitrite test and TTC tests were done. Culture was done by standard loop technique.

RESULTS: The prevalence rate of UTI in pregnancy was $10.40 \%$ i.e., with significant bacteriuria $(1,00,000$ or more bacterial count/ $\mathrm{ml}$ of urine) by Kass concept. The incidence of bacteriuria increased along with age and rising parity. Incidence was similar during all three trimesters. Gram's staining, TTC and Griess nitrite gave $88.46 \%, 73.07 \%$ and $57.69 \%$ respectively correlate with culture positive bacteriurics. CONCLUSIONS: UTI, the most commonly seen complications in pregnancy was $10.4 \%$. Early treatment of bacteriuria not only averts the occurrence of other complications, but also diminishes the risk of premature and perinatal mortality.

KEYWORDS: Bacteriuria; Urinary tract infection; Pregnancy.

1. INTRODUCTION: Urinary tract infection in women is more prevalent and is one of the most frequently seen medical complications in pregnancy ${ }^{1}$. Ideal $\mathrm{pH}$, temperature and constituents like glucose present in urine predispose to bacterial growth ${ }^{2}$. During pregnancy, urethral compression at the pelvic brim by the enlarging uterus leads to stasis of urine, incomplete emptying and residual urine, which is the single most important factor that can initiate the proliferation of microorganisms ${ }^{3}$. Patients with UTI present with classical symptomatology of frequency, urgency, urinary tenesmus, and fever or it may be completely without any symptoms (asymptomatic bacteriuria) ${ }^{4}$.

Journal of Evolution of Medical and Dental Sciences/Volume1/ Issue4/October-2012 Page 315 
The detection of bacteriuria allows an approach to be made for the prevention of chronic urinary disease in the community and to avoid complications in pregnancy at an early stage.

2. MATERIALS AND METHODS: The objective of the study was to know the prevalence of UTI in pregnant women.

A total of 500 urine samples were collected from pregnant women attending KBN Hospital and subjects comprised of varying ages from 18 to 35 years during January to December 2011. Subjects from varying gravida and from all three trimesters were included.

1. COLLECTION OF URINE: Subjects were instructed to collect midstream urine sample with all aseptic precautions in sterile urine container.

2. EXAMINATION OF URINE:

a) Macroscopic examination: Urine was observed by naked eye for altered colour, presence of turbidity, deposit and the findings were recorded.

b) Microscopic examination:

I. A drop of uncentrifuged urine was allowed to air dry. The smear was Gram stained and examined under oil immersion. Twenty fields were examined. Presence of at least one organism per field was considered as significant (? $10^{5} / \mathrm{ml}$ organisms $)^{13}$.

II. For the microscopic examination of urine $10 \mathrm{ml}$ of urine was transferred into conical centrifuge tube. The urine was then centrifuged at $1500 \mathrm{rpm}$ for 5 minutes. The supernatant was decanted, to have sediment suspended in $1 \mathrm{ml}$ volume of urine. This preparation was examined in low and high power. Several fields were searched to identify and count the number of cells, crystals and casts. More than 10 pus cells per high power field were considered as significant 5 .

\section{SCREENING TESTS:}

i) Griess Nitrite Test: $1 \mathrm{ml}$ of urine was taken in a clean sterile test-tube. One $\mathrm{ml}$ of $10 \%$ potassium nitrate was added and incubated at $37^{\circ} \mathrm{C}$ for two hours. To this one $\mathrm{ml}$ of Griess nitrite reagent was added i.e., solution-A: Sulphanilic acid and solution-B: ??-naphthylamine. Development of pink to dark red colour indicates positive test ${ }^{14}$.

ii) Triphenyl tetrazolium chloride test (TTC): $2 \mathrm{ml}$ of urine was taken in a sterile test tube and $0.5 \mathrm{ml}$ of working triphenyl tetrazolium chloride reagent was added. This mixture was incubated at $37^{\circ} \mathrm{C}$ for four hours. Formation of red precipitate indicated a positive test ${ }^{15}$.

\section{PLATING OF URINE SAMPLES:}

STANDARD LOOP TECHNIQUE: Plating of urine was done by standard loop technique on blood agar, nutrient agar and McConkey's agar. 


\section{METHOD:}

I. I Flame a calibrated wire inoculating loop and allow it to cool without touching any surface.

II. Mix the urine thoroughly and remove the top of the container.

III. Insert the loop vertically into the urine to allow urine to adhere to the loop.

IV. Spread the loopful of urine without flaming or re-entering urine, loop is drawn across the entire plate, crossing the first inoculum, which is the centre streak numerous times to produce isolated colonies.

V. Incubate plates for at least 24 hours at $37^{\circ} \mathrm{C}$. Colonies are counted on each plate. The number of CFU's is multiplied by 1000 (if a $0.001 \mathrm{ml}$ loop is used) to determine the number of microorganisms per millilitre in the original specimen ${ }^{6}$.

3. RESULTS: Out of the 500 urine samples collected from pregnant women attending the antenatal clinics, every sample was subjected to routine urine analysis including microscopic examination. Among these 500 samples, the present study revealed that 52 pregnant women had significant bacteriuria $(1,00,000$ or more bacteria/ $\mathrm{ml}$ of urine) giving a prevalence of $10.4 \%$.

Age wise distribution in pregnant women with bacteriuria is shown in table-1. It can be concluded that the incidence of bacteriuria increased with age among the pregnant women. Similarly a positive association is observed between parity of women and bacteriuria. As majority i.e. $24.4 \%$ (11)ut of 45 ) of grand multi para had bacteriuria followed by $10.52 \%$ (8 out of 76 ) with $3^{\text {rd }}$ gravid, $8.7 \%$ of (19 out of 217 ) primi and $8.64 \%$ (14 out of 162)of second gravid had bacteriuria .The incidence was almost thrice when compared to that in the primigravida. Table- 2 reveals that significant bacteriuria during pregnancy had a similar incidence during all the three trimesters.

Significant proteinuria was present in $75 \%$ (39) of bacteriuric cases. However, $13.46 \%$ (7)of the bacteriuric women did not show any proteinuria, $11.54 \%(6)$ bacteriuric women revealed a trace of proteinuria .

Table-3 reveals the correlation of the Gram negative isolates and Gram positive bacteria to the screening tests viz., TTC and Griess nitrite. The TTC test gave an overall better correlation as compared to the Griess nitrite test. However, the correlation with Gram positive bacteria was very poor, being $26.92 \%$. With Gram negative bacilli, it was better, being $46.15 \%$. The Griess nitrite test gave a even more poor correlation, being $38.46 \%$ positive with Gram negative bacilli, and $19.23 \%$ positive with Gram positive bacteria. Table-4 shows the comparison of other screening method with standard loop technique.

4. DISCUSSION AND CONCLUSION: From this study, the prevalence of UTI in pregnancy was $10.4 \%$. Hitherto the studies conducted reveal that the prevalence of bacteriuria during pregnancy ranges from $3-12.8 \%$. This variation is related to factors like socioeconomic status of the group of women studied ${ }^{11,12}$.

It was observed that increasing age or greater parity is associated with a higher frequency of significant bacteriuria ${ }^{7}$. In the present study the incidence of bacteriuria in all the 3 -trimesters was not much different, being $10.9 \%$ in the 1 st trimester, and $10.12 \%$ and $10.45 \%$ in the second and third trimesters respectively. 
The TTC test gave a $73.07 \%$ correlation with culture positive bacteriuria and Griess nitrite gave a $57.69 \%$ positive correlation with culture positive bacteriuria. These two tests could be supportive to culture for bacteriuria, but not conclusive on their own.

The observations made by Simmon and Williams ${ }^{8}$ and Kincaid Smith et $\mathrm{al}^{9}$, for the prevalence of TTC test positive was $94 \%$ and $79 \%$ respectively. Our findings of TTC test positivity of $73.07 \%$ and nitrite test of Griess gave a positivity in 30 cases of bacteriurics (57.69\%).

Mere isolation of microorganisms from the urine does not always mean infection, organisms has to be $1,00,000$ or more/ $\mathrm{ml}$ of urine. When qualitative estimation is carried out indicating growth and multiplication of the organisms in the urinary bladder ${ }^{3}$, Gram positive cocci multiply slowly in the urine as compared to Gram negative bacilli. It has been suggested by Pead et $\mathrm{al}^{10}$ that $10^{4}$ organisms/ $\mathrm{ml}$ of uncentrifuged urine in case of Gram positive cocci should be considered consistent with urinary infection instead of $10^{5}$ bacteria/ ml, which is appropriate for Gram negative bacilli13.

Significant bacteriuria during pregnancy has not yet been accorded the status of a disease despite the isolation of almost similar type of bacterial flora as in the symptomatic cases. However, this study will serve as a reference for researchers interested in this field. Controlled trials and large-scale studies are required to establish pathogenic potential of the isolates. This study has revealed that screening for bacteriuria during pregnancy is an appropriate investigation and that culture was the most effective means of detecting bacteriuria, which may help in the prevention of complications associated with UTI in pregnant women.

\section{Table-1: Age Distribution in Pregnant Women with Bacteriuria}

\begin{tabular}{|l|l|l|l|}
\hline \multirow{2}{*}{ Age (years) } & \multirow{2}{*}{$\begin{array}{l}\text { Total No. of } \\
\text { samples screened }\end{array}$} & Cases with Bacteriuria \\
\cline { 3 - 4 } & & No. & Percentage \\
\hline $18-20$ & 89 & 7 & 7.86 \\
\hline $21-25$ & 203 & 20 & 9.85 \\
\hline $26-30$ & 166 & 16 & 9.64 \\
\hline $31-35$ & 38 & 6 & 15.78 \\
\hline $35 \&$ above & 4 & 3 & 75.00 \\
\hline Total & 500 & 52 & 10.40 \\
\hline
\end{tabular}

Table-2: Relationship of Duration of Pregnancy and Bacteriuria

\begin{tabular}{|l|l|l|l|}
\hline \multirow{2}{*}{ Trimester } & Total No. of & Cases with Bacteriuria \\
\cline { 3 - 4 } & samples screened & No. & Percentage \\
\hline First & 55 & 6 & 10.90 \\
\hline Second & 158 & 16 & 10.12 \\
\hline Third & 287 & 30 & 10.45 \\
\hline Total & 500 & 52 & 10.43 \\
\hline
\end{tabular}


Table-3: Correlation of Screening Tests with Culture Positive Bacteriurics

\begin{tabular}{|l|l|l|l|l|}
\hline \multirow{2}{*}{ Bacteriuric cases on culture } & \multicolumn{3}{l|}{ TTC test positive } & \multicolumn{2}{l|}{ Griess Nitrite Test } \\
\cline { 2 - 5 } & No. & Percent & No. & Percent \\
\hline Gram negative bacilli & 24 & 46.15 & 20 & 38.46 \\
\hline Gram positive bacteria & 14 & 26.92 & 10 & 19.23 \\
\hline Total & 38 & 73.07 & 30 & 57.69 \\
\hline
\end{tabular}

Table-4: Technique wise distribution of cases with significant bacteriuria in comparison with Standard Loop Technique

\begin{tabular}{|l|l|l|}
\hline Name of Technique & No. of Cases & Percentage \\
\hline Standard loop technique & 52 & 100.00 \\
\hline Gram staining & 46 & 88.46 \\
\hline TTC test positive & 38 & 73.07 \\
\hline Griess nitrite test positive & 30 & 57.69 \\
\hline
\end{tabular}

ACKNOWLEDGEMENT: The authors are very much grateful to the Dean, Khaja Banda Nawaz Institute of Medical Sciences, Gulbarga for providing all the necessary facilities.

\section{REFERENCES}

1. MaClean AB: Urinary tract infection in pregnancy. International Journal of Antimicrobial Agents, 2001; 17, 4, 279.

2. Asscher, AW. Urine as a medium of bacterial growth. Lancet-II, 1966; 1037.

3. Pritchard JA, MacDonald PC. Maternal adaptation to pregnancy. Williams Obstetrics, $16^{\text {th }}$ Edition, Appleton Century Croff/ New York, 1976: 211.

4. Kass EH, (1956): Quoted by Whalley, p. 1967.

5. McNeely, Michael. Urinalysis. In: Sonnerwith AC, Jarett L (eds) Gradwall's Clinical Laboratory Methods \& Diagnosis, 8 ${ }^{\text {th }}$ Edn., Vol. I, BI Publications Ltd., New Delhi, 478: 1990.

6. Bailey \& Scott's Diagnostic Microbiology, Chap-60. Infections of the Urinary Tract, 937: 2002.

7. Whalley PJ, Martin FG, Peters PC. Significance of asymptomatic bacteriuria detected during pregnancy. Journal of American Medical Association, 1965; 193: 879.

8. Simmons and Williams. A simple test for significant bacteriuria. Lancet, 1962; 1: 1377.

9. Kincaid Smith P, Bullen M. Bacteriuria in Pregnancy. 1965; 1: 395.

10. Pead C, Cump J, Maskell R. Staphylococcus as urinary pathogen. Journal of Clinical Pathology, 1977; 30: 427.

11. Turck M, Goffee BS, Petersdorf RG. Bacteriuria of pregnancy - relation to socioeconomic factors. New England Journal of Medicine, 1962; 266 (17): 857. 
12. Kaitz AL, Hodder EW. Method for the detection of significant bacteriuria in large groups of patients. Journal of Clinical Pathology, 1964; 17: 498 Quoted by Leigh DA and Williams JD.

13. Mackie and McCartney. Practical Microbiology. Chapter-4, 14th Edn., Elsevier, 2007: p. 84-85.

14. Weltman 0. Griess nitrite test. In: Diagnosis of Urinary Tract Infection. Journal of American Medical Association, 1956; 161: 528 quoted by Schaus R (1956).

15. Simmons and Williams. A simple test for significant bacteriuria. Lancet 1962; 1 : 1377. 